\title{
Internal Control Analysis of Project-Budget Realization In Order To Increase Budgetary Control At PT ABC
}

\author{
Fransisca Utami $^{*}$, Siti Nurwahyuningsih Harahap ${ }^{1}$ \\ ${ }^{1}$ Faculty of Economics and Business, Universitas Indonesia, Depok 16424, Indonesia \\ *fransiscautami@yahoo.com
}

\begin{abstract}
The purpose of this study is to conduct an internal control analysis of project budget realization based on the Committee of Sponsoring Organizations of the Treadway Commission's (COSO's) Internal Control - Integrated Framework. This study is a qualitative case study at a construction company located in Jakarta, Indonesia. The operational activities of the company are carried out by the operational management of the project starting from the tender process, which is getting information about the project tender and determining the tender offer price, following the tender process, throughout project implementation, material ordering, and project subcontracting until the project is completed. This study concluded that internal control of the realization of project budget is very important in monitoring the project implementation. A project-budget-realization report is needed as it can be used to control the progress of the project, in term of timeliness, cost efficiency, and quality.
\end{abstract}

Keywords: Budget, Project, Internal Control, COSO.

\section{INTRODUCTION}

Internal control is very important for a company to be able to operate efficiently and attain growth. Internal control supports all processes imposed by the management and it is designed to provide confidence that the company will achieve its objectives ${ }^{1}$. In addition, internal control is used to maintain the company's assets, minimize the occurrence of the abuse of authority, as well as to identify and manage the company's risks. Ineffective internal control will lead to errors in managerial decision-making, reporting irregularities and loss of the company's assets ${ }^{1}$.

A project is a temporary effort to generate a specific and unique product or service. Each project has a precise purpose and involves various resources, namely cost, time, human resources, materials, and equipment. These resources have to be used optimally to achieve maximum results. To achieve these objectives, there are three constraints that must be taken into account, i.e. the cost to deliver the project, the time to complete the project, and the quality to be met as set in the project contract. These three constraints are important parameters for the implementation of a project to be able to achieve the project objectives 2 .

The project budget is the maximum funds that the project owner is willing to spend on design and construction work. This budget is prepared before the start of the construction work and serves as a "cost estimate". This "cost estimate" used to estimate the cost to be incurred by the firm to manage the required amount of labor and other resources, as well as to determine how much the company must invest to complete the project ${ }^{3}$.

Control over the cost estimate is very important because the actual cost to complete the project is expected to not exceed the budget, both in terms of the cost per item of work and the total cost incurred throughout construction until the end of the project. Cost control is the process of monitoring project performance by using the periodic reports to identify the current project cost and compare it to the budget ${ }^{4}$.

This study has been conducted to analyze the internal control over the realization of project budget, by referring to COSO's Internal Control - Integrated Framework. This study is conducted at PT ABC, a construction company in Jakarta, Indonesia, using case study approach. The results of this study are expected to give highlight on the importance of internal control over the budget realization for a construction company. The operational activities of the company are carried out by the operational management of the project starting from the tender process, which is getting information about the project tender and, determining the tender offer price, and, following the tender process, project implementation, material ordering, and project subcontracting until the project is completed.

\section{LITERATURE REVIEW}

Internal control is a process that is designed and implemented by management to provide reasonable assurance of the reliability of financial and operational information; to provide compliance with procedures, regulations, and laws; to maintain the company's assets, to maintain operating efficiency; to achieve the company's goals and 
objectives; and to maintain integrity and ethical values ${ }^{1}$. According to COSO, internal control is a process that is influenced and designed by management, the board of commissioners, or other personnel to provide reasonable assurance of achieving the company's objectives, namely effectiveness and efficiency of operations, reliability of financial reports, and compliance with policies, regulations, and applicable laws ${ }^{5}$.

COSO's Internal Control - Integrated Framework consists of five components, namely control environment, risk assessment, control activity, information, and communication and monitoring ${ }^{5}$.

Implementation of internal control requires monitoring and evaluation to ensure that all five internal-control components are functioning properly. The results of this evaluation will be reported to the management, the board of directors, and the parties responsible, so that the company can take corrective action ${ }^{1}$.

These five components of COSO's Internal Control - Integrated Framework must be run by the company in order to attain effective internal control. These five components help the company to keep focused on implementing internal controls so that company's objectives can be achieved, risks can be reduced to an acceptable level, and the company becomes adaptable to business, operational, and regulatory changes ${ }^{1}$.

The five components of the internal-control framework, as previously discussed, will be used as a reference to analyze the effectiveness of internal control over budget realization. Therefore, it is necessary to discuss the phases of tender and budget realization, to give an understanding of the business process in a construction company. The phases of tender and budget realization are discussed briefly, as follows: ${ }^{6}$

\section{Receipt of Tender Invitation}

The construction company seeks information about the project tender through publications in the newspapers or through the procurement process. The construction company may also receive an invitation directly from the project owner.

\section{Aanwijzing and Location Survey}

This phase is the initial phase of the tender process. This phase is executed by the construction company to produce project artifacts such as drawings, work plan, terms and conditions, and the bill of quantity (BQ), and to conduct a survey of the project site. If the construction company is interested in responding to the tender, it will prepare all the documents required, based on the work plan, and terms and conditions. The company will also prepare the BQ, based on the work volume and price.

\section{Submission of Quotation}

In this phase, all the required documents, including the $\mathrm{BQ}$, will be handed over to the quantity surveyor or the tender committee of the project owner. The quantity surveyor will again check all the documents, in particular the $\mathrm{BQ}$, that were submitted by the construction company.

\section{Clarification}

This phase is conducted to assess the qualification of the construction company by checking the administrative documents that were submitted by the participants. Within this phase, the project owner and the tender participant make sure that they have the same perception of the project drawing, so that they have a similar estimate of project volume. During this phase, the tender participants have the opportunity to discuss and ask questions about the project drawing to ensure that there are similarities between the volume calculations of the project owner's quantity surveyor and those of the construction company. If there are still differences in the volume calculations, the construction company may include the volume difference in the added/removed work.

\section{Price Revision}

This phase will be conducted if there is a calculation difference between the construction company and the quantity surveyor of the project owner. The construction company can revise the calculation to be close to the project owner's calculation. This calculation revision will be sent back to the quantity surveyor or the tender committee of the project owner.

\section{Final Negotiation}

After all the quotation documents have been submitted to the quantity surveyor of the project owner, then the next phase is the final-price negotiation. In this phase, the quantity surveyor or the tender committee will offer a minimum price to the construction company. The quantity surveyor can offer a lower price than the price that the construction company has submitted. If the construction company accepts the price from the quantity surveyor and is declared the tender winner, the construction company should revise the price according to the agreement with the quantity surveyor. From the results of this final negotiation, the quantity surveyor or the tender committee of the project owner will make a list based on the prices submitted by the tender participants from the lowest price to the 
highest price.

\section{Determination of the Winner}

Based on the bid list and administration document, the quantity surveyor or the tender committee will make the selection to determine the winner of the tender.

\section{Revision of the Unit Price According to the Contract Value}

According to the description in the final negotiation phase, the construction company that has been declared the tender winner must revise its price according to the agreement with the quantity surveyor of the project owner. The price from the final negotiation phase is the contract value of the project work.

\section{Work-Order Letter}

The project owner will issue a work-order letter to the construction company that is declared the tender winner. The work-order letter is a command to start activities immediately at the site of the named work package, the duration of the work implementation and the value of the work.

\section{Preparation of the Project Budget}

Construction company will prepare the project budget according to the final price that was submitted at the time of the tender. The project budget was constructed based on architectural drawings and structures (drawing bestek), work plan, terms and conditions, analysis reports, aanwijzing reports, the price list of materials used, the price list of services for each job, and the volume list for each job.

\section{Project Implementation}

After the construction company receives a work-order letter from the employer and prepares the project budget, the construction company is ready to start the project activities. At this stage of the project implementation, the construction company may bill the project owner based on progress or completed work.

\section{Preparation of Project-Budget-Realization Report}

After all the work is done, the construction company prepares the project-budget-realization report. This report should include all unexpected costs to give the information of the actual cost of construction project. This "actual completion cost" is compared to the specified project budget so it can be used to identify and explain discrepancies from the project budget.

\section{RESEARCH METHOD}

The research method used in this study is the qualitative case study. A qualitative approach is a research method that is chosen based on a particular phenomenon, or describes the events that occur and provides solutions through recommendations that are made based on a deep contextual analysis, and experiences based on personal opinions and intuition related to the phenomenon or event. ${ }^{7}$ The data sources and data-collection techniques used in this study are:

\section{Primary Data}

The primary data in this study was obtained through interviews with the operational division of the project's logistics division, budget division, and accounting and finance division, and direct observations at the project site. The purpose of this data collection is to find out the actual conditions, and to identify problems and potential solutions to the problems.

\section{Secondary Data}

The secondary data was obtained through the study of literature study in particular and of the company's documents relating to the control of the realization of the project budget. This was in order to get a general understanding of the process and identify the problems that occur.

\section{RESULTS AND DISCUSSIONS}

The analysis was conducted to find the cause and the effect of problems, based on the gap between the existing conditions and the best practices for internal control according to the COSO's Internal Control - Integrated Framework. Then, alternative solutions to the problem were proposed to strengthen internal control over budget realization at the construction company PT ABC.

For Component 1, based on interviews with the management of PT ABC, the company does not have a code of ethics, which gives guidance for maintaining relations with internal and external parties, including with employees, 
suppliers, subcontractors, project owners, and contractor consultants. The company also does not have a selection procedure for suppliers or subcontractors, so selection is done through connections or personal relations with the manager, company employees, or project leaders. Regular suppliers and subcontractors are those that have close connections to PT ABC's personnel, which is a condition that allows for the occurrence of collusion in pricing of the tender budget (BQ).

The company also has no rules or guidelines for addressing ethics-related violations, and does not have performance-evaluation procedures for individuals and business units that are related to ethical conduct, so there are no sanctions based on the type of ethical fraud committed.

Based on interviews with the human resources (HR) division of PT ABC, the company already has employee recruitment and selection procedures. The company also has placed its employees according to their educational background. From the total number of permanent employees of PT ABC, 81.09\% are placed in a position based on their educational background. The key positions (top management) are held by the founder family, which is typical for a closely owned family company in Indonesia, such as PT ABC.

Company does not have a measure of performance, or incentives and rewards for employees, especially employees in the operations divisions. The company also does not have the procedures or mechanisms to maintain and develop competent individuals, or develop special skills by providing training and giving promotions, especially for project employees. Under these conditions, it is hard for the company to get the best performance from its employees. PT ABC regularly experiences delays in the completion of projects, spends project costs that exceed the project budgets, and delivers project output that does not meet the quality standards. This is not only because the employees are not well trained but also because the employees have no incentives to complete the project in a timely manner, within the budget, and at the required quality. These conditions pose significant threats for PT ABC as it may lead to financial problems or litigation by the project owners.

On the interviews with the financial division of PT ABC, the company does not have an audit committee or an internal audit function, so the supervision and monitoring of the implementation of internal control is not optimal. There are no assessments of internal control; no evaluations of company activity, either financially or operationally; and no evaluations of compliance with regulations related to budget preparation, supplier and subcontractor selection, realization of the budget, and assessment of the project's budget performance. In addition, the company has no control over the suitability, relevance, and reliability of operational reports and financial statements for directors and other users.

Based on the interviews with some of the managers of PT. ABC, the management prefers to take risks in running the business rather than to give priority to the internal control procedures. At PT ABC there is no clear assignment of responsibilities and no distinct division of tasks. Management does not require project managers and site managers to create project-cost-realization reports so the actual cost cannot be compared to the project budget. Consequently, project spending over the budget cannot be identified, the financial performance of the company cannot be accurately measured, and there is no feedback to avoid inefficiencies for future projects.

As can be seen from the company's organizational structure and the outcomes of the interviews with the HR department, there are no specific marketing or planning positions. The marketing position is handled by the project leader or site manager, while the planning position is handled by the project estimator. These dual positions create overlapping authority, responsibilities, and job descriptions, and eliminates the important control through segregation of duties.

Based on interviews with the HR division, PT ABC does not have company regulations that contain rules about the relationships between the company and its employees, or company policies regarding the rights and obligations of the employees, including policies on employee training.

Company management does not have a policy for conducting employee-performance assessments based on the employee's competence and contribution to the company. PT ABC also does not have a compensation policy for employees in accordance with their performance, so that a project manager who successfully completes the project in a timely manner does not have a performance assessment and appreciation based on the performance achieved.

For Component 2, based on interviews with the engineering division and budget division, the management of PT ABC does not identify, evaluate, and analyze the company's risks. According to the engineering division and budget division, the identification and assessment of risks are especially important for the BQ, since it will be used for the bidding process and will function as the project budget if PT ABC is declared the tender winner.

Here some of the risks identified by the engineering division and the estimator in the preparation of the BQ, are as follows:

- There is a risk of errors in the administration of the project tender due to inaccurate information about the type of contract, the duration of the execution, the type and amount of warranty used, or the termination of payment. 
- There is a risk of errors in the calculation of costs due to a lack of attention to environmental conditions at the site and it did not consider unexpected expenses associated with the environment around the site, such as security costs, and compensation for citizens and contributing organizations.

- There is a risk of errors in calculating the volumes and price due to the estimator not being able to accurately to read the tender drawing, or them having a different perception from the construction consultant or project owner about the tender drawing, which can affect the calculation.

- Engineering and budget divisions have limited references for suppliers and subcontractors because the company does not have assessments and selection procedures for new suppliers and subcontractors. This means there is a risk that the company cannot obtain a competitive price for materials.

- There is a risk due to price fluctuation for some material types.

- There is a risk that suppliers and subcontractors are unable to provide materials, or work in accordance with the specifications, volume, and quality required.

- There is a risk that errors occur when entering numbers or unit prices of materials into a draft BQ.

- There is a risk of damage to the received materials.

- There is a risk that materials will be wasted.

- There is a risk that there will be an excess in the calculation of the quantity of work.

- There is a risk that there is an error in the calculations for the implementation of the project.

- There is a risk that there is an error in the calculation of daily work hours.

- The lack of negotiations with suppliers and project leader means that there is a risk that

- The board of directors did not re-check the volume and price, but only looked at the contractor fees contained in the BQ because these fees will affect the value of the project contract.

- The absence of a risk assessment in the budget-preparation activities allows the occurrence of miscalculations and misperceptions in the preparation of the $\mathrm{BQ}$. When the price of the $\mathrm{BQ}$ is high compared to those prepared by other tender participants, then PT ABC will miss opportunities to win the project. On the other hand, when the price of the $\mathrm{BQ}$ is too low compared to those of the other participants, PT ABC will not generate sufficient margin from the project, and, in the long run, may encounter financial problems.

Component 3, based on the interviews with project leaders and site managers, PT ABC's management does not review and evaluate the control system. The company's control system is an old, long-standing system. Therefore, management needs to review and evaluate the internal control system and company's operational activities periodically so that weaknesses or a lack of control system can be addressed immediately.

The control of a project is conducted to ensure that there are no budget deviations in the project implementation so the project can be completed in accordance with the budget amount that was determined.

The management of PT ABC needs to apply sanctions to individuals who have created irregularities or committed fraud. These irregularities or frauds may prevent the company from achieving its objectives because the irregularities or frauds can allow or encourage individuals or groups of employees to commit further fraud, which can cause harm to the company.

For Component 4, PT ABC has not implemented an internal whistleblower system that allows employees to anonymously communicate with management if there is deficiency in the procedure. PT ABC also does not have a mechanism or procedure conducted through a website, telephone, or official facsimile. This communication is to ensure the compatibility and integrity of project construction through advice and input from external parties.

For Component 5, based on interviews with project leaders and site managers, the absence of a liability mechanism causes a lack of project management control, so there is an opportunity for violations, especially those related to budget execution. At the end of the project implementation, the project manager and the site manager are not required to prepare a project-cost-realization report, so the project managers and site managers are not liable for the realization of the project budget.

The BQ that serves as the project budget provides an opportunity for manipulation. The BQ includes a component for supplier or subcontractor fees that are known to be required by project managers and site managers. This disclosure allows project managers and site managers to negotiate prices directly with the suppliers or subcontractors used on the site.

The company has a policy that the site manager can purchase materials directly on the site, up to a maximum limit of Rp2,000,000.00 (two million rupiah). This condition allows irregularities to occur in the purchase of materials on the site as a result of there being no authorization of such purchases by head office.

\section{CONCLUSION}

Based on the aforementioned analysis and discussion, it can be concluded that the internal control of the realization of project budget in PT ABC, according to COSO's Internal Control - Integrated Framework, is insufficient. There are some gaps between the existing conditions at PT ABC and the best practices, which 
potentially cause irregularities. These irregularities are potential threats to the project management of PT ABC, which can cause harm to the company's sustainability and even cause a risk of litigation from project owners.

The supervision of internal-control activities by management is not optimal with respect to the realization of project budget. It is apparent that management does not require project managers and field managers to create a project-budget-realization report, so project managers and field managers are unaware of the "true" projectcompletion costs. This means the project managers and the field managers are unaware of any deviations of project costs or how much of a deviation to the project budget it is.

The management should improve the control environment within the company by generating codes of ethical behavior. The management should be able to assess the competence of each employee, and should also have a performance assessment, incentives and rewards for employees, and policies or procedures to maintain or develop competent individuals within the company. The management should have an audit committee and an internal audit function in order to supervise the implementation of projects with respect to the project budget. The management must consider risks when running the business, and prioritize the procedures for running the company's operational activities by implementing liability mechanisms or procedures. The management should clarify the job description of each employee, so that each employee can have a meaningful performance evaluation. The management of PT $\mathrm{ABC}$ should have company regulations as the basis for establishing other policies related to human-resource development.

The management should identify, assess, and analyze the risks in relation to the implementation of the project budget, and communicate the results to the board of directors and other relevant parties.

The management should periodically review and evaluate the internal control system related to the realization of the project budget by using specific criteria or a standard evaluation of the internal control system.

The management should improve communication between the board of directors and employees, and implement a whistleblower system, both internal and external to the company, especially one that is related to the projectbudget procedures and project implementation.

The management should require project managers to create a project budget as the basis for the project implementation, and create and evaluate a project-budget-realization report.

There are some limitations in this research. The internal-control analysis is limited to the realization of project budget and procedures related to the realization of the project budget, and does not include all procedures within the company. This research was conducted using a case-study approach for PT ABC, so the results may not be able to be generalized to other research objects.

\section{REFERENCE}

[1] Moeller, Robert R. (2009). Brink’s Modern Internal Auditing. Hoboken, New Jersey: John Wiley \& Sons, Inc.

[2] Schwalbe, Kathy (2015). An Introduction to Project Management. USA: Schwalbe Publishing.

[3] Oberlender, Garold D. (2000). Project Management for Engineering and Construction. USA: McGraw-Hill.

[4] Pastiarsa, Made (2015). Menyusun Estimasi Biaya Proyek. Yogyakarta: TEKNOSAIN.

[5] Committee of Sponsoring Organization of the Treadway Commission's. (2013). Internal Control- Integrated Framework.

[6] Dimyati, Hamdan H.A. dan Nurjaman, Kadar (2014). Manajemen Proyek. Bandung: PUSTAKA SETIA, CV.

[7] Sekaran, Uma (2003). Research Methods for Business. USA: John Wiley \& Sons, Inc. 